\title{
Is Article 2 Regulatory or Facilitatory? A Socratic Dialogue
}

\author{
SCOTT J. BURNHAM*
}

Statutes generally serve a regulatory function. Article 1 of the Uniform Commercial Code, however, expressly tells us that "[t] he effect of provisions of this Act may be varied by agreement," making the function of that set of statutes generally facilitatory. The confusion caused by these dual roles of the Code is the "commercial calamity" explored in this dialogue between professor and student.

In today's commercial law class, we are going to talk about one of the most important principles of contract law-freedom of contract. Parties generally have the power to agree to the terms that will bind them.

You say "generally." That suggests an exception.

This is law, so there are always exceptions. Our freedom of contract has a number of constraints. Common law restrictions are of course a restraint, for the principle of stare decisis tells us what was not permitted in the past will probably not be permitted in the future. (Note that I cleverly inserted that "probably" to suggest there will be exceptions to this principle as well.) And of course legislatures have the power to regulate transactions.

Are any of those legislative acts relevant to the subject at hand?

An agreement for the sale of goods is governed not only by the terms the parties agreed to, but also by the provisions of Article 2 of the Uniform Commercial Code.

Is that a statute?

Sort of. The Uniform Commercial Code (U.C.C. or Code) is a uniform law promulgated by the National Conference of Commissioners on Uniform State Law (NCCUSL) and the American Law Institute (ALI). ${ }^{1}$ To become law, however, the U.C.C. must be enacted by a state.

So it becomes a uniform law because every state enacts the same law?

That is the theory, ${ }^{2}$ but it doesn't work out that way in practice. State legislatures are sometimes perversely unwilling to agree with the language of the uniform law, so they exercise their right to change it. The result is that there is no single U.C.C., but instead a Montana U.C.C., a New York U.C.C.,

* Professor of Law, The University of Montana School of Law.

1 See Symposium, Perspectives on the Uniform Laws Revision Process, 52 Hastings L.J. 603 (2001).

2 U.C.C. $\S 1-102(2)(c)$ (2000) [U.C.C. $\$ 1-103(a)(3)$ (revised 2005)] provides that one of the "[u]nderlying purposes and policies of this Act" is "to make uniform the law among the various jurisdictions." Id. 
etc. ${ }^{3}$

So the Uniform Commercial Code isn't really "uniform"?

Right. Even though Article 2 of the U.C.C. has been enacted in every state, each state has a slightly different version of it.

But since it is enacted as a body of law, it is a code.

Sort of. ${ }^{4}$ You know that the legislature has the primary lawmaking function. And statutes enacted by the legislature generally create or negate rights - they tell us what we can and cannot do. And a code is "a complete system of positive law." But the U.C.C. is not particularly complete -it is full of holes. Perhaps the second-most important Code provision, section 1-103, explains how to fill in those holes. ${ }^{6}$ That section provides, "Unless displaced by the particular provisions of [the Uniform Commercial Code], the principles of law and equity ... supplement its provisions."7

I'm surprised to hear that a statute would displace principles of equity. Isn't it the function of equitable principles to do justice in cases where application of the literal language of the statute would not?

I agree. I think that provision means that principles of law may be displaced by the Code, but principles of equity only supplement the Code. ${ }^{8}$

I notice you just referred to a statute from Article 1. How does that article fit in with the rest of the Code?

A reasonable person might think that the provisions in Article 1 apply only to the rest of the Code, but the Code does not say that, and some courts have applied Article 1 to non-Code transactions. ${ }^{9}$ Now that relationship is made explicit by Revised section 1-102, which provides: "Scope of Article. This article applies to a transaction to the extent that it is governed by another

${ }^{3}$ See U.C.C. § 1-101 (2000) [U.C.C. § 1-101(a) (revised 2005)].

4 "The resulting Code is utterly unique, even among codes." John L. Gedid, U.C.C. Methodology: Taking a Realistic Look at the Code, 29 WM. \& MARY L. REV. 341, 342 (1988).

5 BLACK'S LAW DICTIONARY 273 (8th ed. 2004). "Strictly, a code is a compilation not just of existing statutes, but also of much of the unwritten law on a subject, which is newly enacted as a complete system of law." Id. at 273-74.

6 I know you can't stand the suspense, but we will get to the most important provision momentarily.

${ }^{7}$ U.C.C. $\$ 1-103$ (2000) [U.C.C. $\$ 1-103(b)$ (revised 2005)].

${ }^{8}$ See specifically Robert S. Summers, General Equitable Principles Under Section 1-103 of the Uniform Commercial Code, 72 Nw. U. L. REV. 906, 936-42 (1978). See generally RoBert A. HillmaN, JuliaN B. MCDONNELl \& STEVE H. NiCKLES, COMMON LAW AND EQUITY UNDER THE UNIFORM COMMERCIAL CODE (1985).

${ }^{9}$ Examples are found in 1 HAWKLAND, UNIFORM COMMERCIAL CODE SERIES [Rev.] $\S 1-102: 1(2002)$. 
article of the Uniform Commercial Code."10

What does it mean when you refer to a Revised section of the Code?

One of the advantages of the common law over statutory law is that the common law is more flexible in adapting to changing conditions. This is a particular concern in the area of commercial law, where it is important for the law to keep up with changing commercial practices. As we will see later, the Code tries to build in some of that flexibility, but even so, it needs periodic revision. So the promulgators of the Code have adopted a revision of Article 1 that they are now trying to get states to enact.

Have they been successful?

Not exactly. A number of states have enacted Revised Article 1, but none has enacted it in its uniform version. ${ }^{11}$

So we've seen that the Uniform Commercial Code isn't really "uniform" and it isn't really a "code." But since it is a statute, it does regulate certain transactions?

Not exactly. In general, Article 2 is not regulatory, but facilitatory-instead of telling the parties what they can and cannot do in their contract, it helps the parties make their contract by filling in the terms that they don't expressly provide.

So it tells the parties what the terms of the contract are?

Not exactly. It provides default rules that govern the contract in the absence of the parties' agreement. But the parties are generally free to change the Code's default rules. That freedom of contract principle, found in section $1-102(3),{ }^{12}$ is probably the most important Code provision.

That's bad news, because I'm having a little trouble reading that provision.

Let me see if I can help. The section states the general rule that " $[t]$ he effect of provisions of this Act may be varied by agreement." That principle is limited by two exceptions: 1) "except as otherwise provided in this Act," and 2) "except that the obligations of good faith, diligence, reasonableness and care prescribed by this Act may not be disclaimed by agreement." There is then a qualification of the second exception. ${ }^{13}$

${ }^{10}$ U.C.C. $§ 1-102$ (revised 2005).

${ }^{11}$ For a tally of states that have enacted Revised Article 1 and an enumeration of the differences among enacted versions, see the web site of Professor Keith Rowley at http://www.law.unlv.edu/faculty/rowley/ral_updates.htm (last visited Feb. 11, 2007).

12 U.C.C. $\S 1-102(3)$ (2000) [U.C.C. § 1-302 (revised 2005)].

${ }^{13}$ Id. David Mellinkoff put the provision in the category of the "long, long sentence." David Mellinkoff, The Language of the Uniform Commercial Code, 77 YALE L.J. 185, 217 (1967). "With the long, long sentence, it is an easy matter to dump a problem and forget it, to assume it is taken care of because mentioned, without too much concern about what human beings may make of it." Id. I think Mellinkoff would be pleased with the revision, 
I notice that a lot of the provisions of Article 2, particularly in Part 3, state that the rule applies "unless otherwise agreed" by the parties. So that language carries out the freedom of contract principle that we are generally free to vary provisions by agreement, right?

Right.

I vaguely recall a principle of statutory interpretation that goes by the Latin name expressio unius est exclusio alterius - the expression of one thing excludes another. So applying that principle here, doesn't that mean that where the Code does not say the rule applies unless otherwise agreed, then it applies even if the parties did otherwise agree? That is that how we spot a regulatory rule-right?

That might be a reasonable interpretation, but the Code tells us otherwise. Section 1-102(4) provides: "[t]he presence in certain provisions of this Act of the words 'unless otherwise agreed' or words of similar import does not imply that the effect of other provisions may not be varied by agreement under subsection (3)."14

So we can vary a rule if the words "unless otherwise agreed" aren't there?

Not exactly. The Code says that the presence of the "unless otherwise agreed" language in one provision does not imply that we may not vary other rules. But that is not the same as saying that the absence of that language from a provision means that we may vary that rule.

But the first exception to section 1-102(3) states that we can't vary provisions by agreement where it is "otherwise provided in this Act."15 So to find the regulatory rules, we just have to look for a provision that we can't vary, right?

There is a list of such provisions in Article 9.16

Where is the list found in Article 2?

It isn't.

So since it is nowhere "otherwise provided," we can vary all the provisions of Article 2 except the ones expressly enumerated in the second exception to section 1-102(3)?

No. Even if a provision does not expressly state that it may not be varied by agreement, the prohibition on variation may be implied.

Can you give us an example?

There are a number of such provisions. ${ }^{17}$ One of them is our old friend

which breaks the rule down into two subsections, the second of which contains three sentences.

14 U.C.C. $\S 1-102(4)$ (2000) [U.C.C. $\S 1-302($ a) (revised 2005)].

15 U.C.C. $\$ 1-102(3)$ (2000) [U.C.C. $\$ 1-302$ (revised 2005)].

16 See U.C.C. $\$ 9-602$ (2005).

17 Professor Sarah Jenkins of The University of Arkansas at Little Rock kindly 
section 2-302. ${ }^{18}$ It is worded in terms of a court's power to declare contract provisions unconscionable. But it is regulatory because it advises us that if we put unconscionable provisions in contracts, we are in danger of not having them enforced. Our behavior is channeled into not putting unconscionable provisions in our contracts.

So that's a good example of where the law is "displaced" by a particular provision of the Code.

I don't think so. This is probably the rule at common law anyway. ${ }^{19}$

supplied me with this list of Article 2 provisions that are probably regulatory: $\S 2-201$ Formal Requirements; Statute of Frauds (general public policy goals of preventing perjury and fraud and promoting certainty, deliberateness, and caution); $§ 2-202$ Final Written Expression in a Record: Parol or Extrinsic Evidence (a substantive rule governing the kind of evidence that courts may consider in the process of determining the terms of the parties' agreement or for interpreting the terms of the agreement; a general public policy goal of giving deference to a writing intended by the parties as a final expression of some or all of the terms of their agreement); $\S 2-302$ Unconscionable Contract or Clause (a substantive tool designed to encourage uniformity in policing bargains to prevent oppression and unfair surprise); § 2-318 Third Party Beneficiaries of Warranties Express or Implied (each alternative of this provision expressly prohibits the exclusion or limitation of a seller's liability to third parties for warranties made by the seller to its buyer); $\S 2-603$ Merchant Buyer's Duties as to Rightfully Rejected Goods (the language of this section is mandatory rather than discretionary, and the duty to follow the seller's instructions or to resell when none are given is imposed as a matter of good faith and commercial necessity); $\S 2-715(2)(a)$ Buyer's Incidental and Consequential Damages (general public policy of a buyer's duty to mitigate damages); $\$ 2-718$ Liquidation or Limitation of Damages; Deposits (reasonableness limitation on liquidated damages); $\$ 2-719$ Contractual Modification or Limitation of Remedy (agreement must provide a "fair quantum" of a remedy; limitation of consequential damages cannot be unconscionable); $\S 2-725$ Statute of Limitations in Contracts for Sale (the provision expressly limits variation to not less than one year and not more than four years).

18 U.C.C. $\$ 2-302$ (2000) provides:

Unconscionable Contract or Clause.

(1) If the court as a matter of law finds the contract or any clause of the contract to have been unconscionable at the time it was made the court may refuse to enforce the contract, or it may enforce the remainder of the contract without the unconscionable clause, or it may so limit the application of any unconscionable clause as to avoid any unconscionable result.

(2) When it is claimed or appears to the court that the contract or any clause thereof may be unconscionable the parties shall be afforded a reasonable opportunity to present evidence as to its commercial setting, purpose and effect to aid the court in making the determination.

Id. See generally Arthur Allen Leff, Unconscionability and the Code-The Emperor's New Clause, 115 U. PA. L. REV. 485 (1967).

${ }^{19}$ See Williams v. Walker-Thomas Furniture Co., 350 F.2d 445, $448-49$ (D.C. Cir. 
So if it is the rule anyway, what function is served by having the Code declare the rule?

Perhaps there is utility in making the rule clear. ${ }^{20}$ In serving this function, the Code operates like a restatement, putting the rule in a concise and accessible form.

That's good, because I'm always getting the Code and the Restatement confused anyway.

Please don't do that. Although I will admit that the Restatement (Second) of Contracts sometimes looks a lot like Article 2 of the Code, which has had a powerful impact on the general law of contracts. ${ }^{21}$

The Restatement seems so wishy-washy, with its standards, factors, and considerations of justice. Wouldn't commercial law be better off with black-letter rules that provide more predictability?

You sound like our economist friends. They say that the reason so many Article 2 provisions read the way they do is because the only way to get the broad consensus required for approval is through vagueness. ${ }^{22}$

I do notice that Article 2 throws that word "reasonable" around a lot. I guess it is hard to argue with that concept, for who wants to claim that you don't have to be reasonable, but how come it sometimes says "commercially reasonable?"'

The principal drafter of Article 2, at least in its early stages, was the legal realist Karl Llewellyn. ${ }^{23}$ Llewellyn believed that many norms in the commercial world could be objectively determined by asking those involved in the particular transactions what they were. ${ }^{24}$ In that context, a

1965) (holding that courts have historically possessed this power).

20 It was not so obvious, for example, to the trial court and intermediate courts in Williams, which thought that in the absence of legislative enactment, its hands were tied. Id. at 447-48 (citing Williams v. Walker-Thomas Furniture Co., 198 A.2d 914, 916 (D.C. 1964)).

21 See, e.g., RESTATEMENT (SECOND) OF CONTRACTS $\$ 33(2)$ (1981) and U.C.C. $\S 2-204(3)$ (2000); RESTATEMENT (SECOND) OF CONTRACTS $\S 251$ (1981) and U.C.C. $\S 2-609$ (1) (2000); see generally Robert Braucher, Freedom of Contract and the Second Restatement, 78 YALE L.J. 598 (1969) (discussing changes in the Second Restatement, some of which were caused by the drafting of the U.C.C.).

22 See Alan Schwartz \& Robert E. Scott, The Political Economy of Private Legislatures, 143 U. PA. L. REV. 595, 598 (1995) ("[T]he proportion of rules and standards in the ALI's and NCCUSL's output is much more a function of the structural features of these organizations than it is a function of conscious policy choice.").

23 See Allen R. Kamp, Uptown Act: A History of the Uniform Commercial Code: 1940-1949, 51 SMU L. REV. 275, 279 (1998); Allen R. Kamp, Downtown Code: A History of the Uniform Commercial Code 1949-1954, 49 BUFF. L. REV. 359, 364 (2001).

24 See Allen R. Kamp, Between-the-Wars Social Thought: Karl Llewellyn, Legal Realism, and the Uniform Commercial Code in Context, 59 ALB. L. REV. 325, 339-45 
"commercially" reasonable norm is applicable only to those who are regularly involved in that particular commercial transaction. Official Comment 1 to section 2-104 begins, "This Article assumes that transactions between professionals in a given field require special and clear rules which may not apply to a casual or inexperienced seller or buyer."25

And because it is a "commercial" code, the rules only apply to those "professional" parties, right?

No. According to section 2-102, "this Article applies to transactions in goods." 26 There are a few provisions (fourteen in fact) that apply only to merchants or only between merchants, ${ }^{27}$ but otherwise the provisions of Article 2 apply whether the parties are merchants or not. So in general, the term "commercial" appears to be used in the broad sense of "involved in commerce," but it is sometimes used in the narrow sense of "having experience in commerce."

So the Uniform Commercial Code, in addition to not really being "uniform" and not really being a "code," isn't really "commercial"?

That's right. If you and I make a contract for the sale of a pen for 29 cents, it is governed by the Uniform Commercial Code. ${ }^{28}$

But, because we're not merchants, we don't have to be "commercially reasonable."

Right, we only have to be reasonable. For example, section 2-607 requires the buyer to give the seller notice of a breach "within a reasonable time." Official Comment 4 contains a good explanation of the distinction between applying this standard to a commercial party and to a non-commercial party:

The time of notification is to be determined by applying commercial standards to a merchant buyer. "A reasonable time" for notification from a retail consumer is to be judged by different standards so that in his case it will be extended, for the rule of requiring notification is designed to defeat

(1995-1996). Kamp notes "Llewellyn's first drafts of the Code provided for a jury composed of merchants to make [factual] determinations." Id. at 340; see also David Ray Papke, How the Cheyenne Indians Wrote Article 2 of the Uniform Commercial Code, 47 BUFF. L. REv. 1457, 1459-60 (1999).

${ }^{25}$ U.C.C. $\S 2-104 \mathrm{cmt} .1(2000)$.

26 U.C.C. $\$ 2-102(2000)$.

${ }^{27}$ See Ingrid Michelsen Hillinger, The Article 2 Merchant Rules: Karl Llewellyn's Attempt to Achieve The Good, The True, The Beautiful in Commercial Law, 73 GEO. L.J. 1141,1143 n.11 (1985).

${ }^{28}$ See Scott J. Burnham, Why Do Law Students Insist That Article 2 of the Uniform Commercial Code Applies Only to Merchants and What Can We Do About It?, 63 BROOK. L. REV. 1271, 1271 (1997). 
commercial bad faith, not to deprive a good faith consumer of his remedy. ${ }^{29}$

Aren't all parties bound to act in good faith?

Right. That is the rule of section $1-203,{ }^{30}$ and you will recall this is one of the rules section 1-102(3) says can't be varied. ${ }^{31}$

But the definition of "good faith" in Revised section 1-201(b)(20) provides that it means "honesty in fact and the observance of reasonable commercial standards of fair dealing." 32 So even if you and I aren't commercial parties, are we nevertheless held to "the observance of reasonable commercial standards of fair dealing"?

I don't think so. Note that the definitions in Revised section 1-201(b) are prefaced by subsection (a), which provides that "[u]nless the context otherwise requires," the word has the defined meaning. ${ }^{33}$ Perhaps this is an example of where the context otherwise requires.

That second exception in section 1-102(3) regarding obligations that we can't vary enumerates not only good faith, but diligence. I couldn't find any obligation of diligence in Article 2. So we don't have to worry about that, right?

I wouldn't say that. That obligation is probably there, but it is just not called the obligation of diligence. For example, in section 2-306(2), where there is "an obligation by the seller to use best efforts to supply the goods and by the buyer to use best efforts to promote their sale," 34 Official Comment 5 says the parties have "bound themselves to use reasonable diligence." 35

Let me see if I can apply what we have learned so far to a concrete example. Take the statute of frauds in section 2-201. The rule states that an oral contract for the sale of goods for a price of $\$ 500$ or more is not enforceable. It doesn't say that it cannot be varied by agreement. So we can agree that we want our $\$ 600$ contract to be enforceable even if oral?

I don't think so. This provision is regulatory, though I'm not sure exactly how we know that. But Official Comment 2 to section 1-102 tells us:

This principle of freedom of contract is subject to specific exceptions found elsewhere in the Act and to the general exception stated here. The

${ }^{29}$ U.C.C. $\$ 2-607 \mathrm{cmt} .4(2000)$.

30 U.C.C. $\S 1-203(2000)$ [U.C.C. $\S 1-304$ (revised 2005)].

31 U.C.C. $\S 1-102(3)(2000)$.

32 U.C.C. $\S 1-201(b)(20)$ (revised 2005). Except it doesn't mean that in Article 5. See U.C.C. $\S 5-102(a)(7) \mathrm{cmt} .3(2005)$.

33 U.C.C. $\$ 1-201$ (a) (revised 2005).

34 U.C.C. $\$ 2-306(2)(2000)$.

35 U.C.C. $\S 2-306(2) \mathrm{cmt} .5(2000)$. 
specific exceptions vary in explicitness: the statute of frauds found in Section 2-201, for example, does not explicitly preclude oral waiver of the requirement of a writing, but a fair reading denies enforcement to such a waiver as part of the "contract" made unenforceable. ${ }^{36}$

So we should get the rules out of the Official Comments?

No. Because the Official Comments are not enacted by the legislature, they do not have the force of statutes (whatever force these statutes have), so you should not cite them for rules. But you can cite them for guidance.

So, to recap, some provisions are regulatory and others are facilitatory, though it may be a struggle to determine which is which.

Yes.

And where it is a facilitatory rule, we are more or less free to change it.

Yes.

But where a rule is either expressly or impliedly a regulatory rule, then that rule has to be followed.

Not exactly. We mentioned earlier that the Code tries to build in some of the flexibility of the common law. Section 1-102(1) states that " $[t]$ his Act shall be liberally construed and applied to promote its underlying purposes and policies," which are then stated in subsection (2). ${ }^{37}$

Can you give us an example of where the Code has been liberally construed?

Section 2-609 provides the procedure for a demand for assurances, which is a handy way to determine whether the other party has breached by anticipatory repudiation. It states that the demand must be made "in writing." But if the demand is made orally rather than in writing, it may still be

36 U.C.C. $\S 1-102 \mathrm{cmt} .2$ [see U.C.C. $\S 1-302 \mathrm{cmt} .2$ (revised 2005)].

37 U.C.C. $\S 1-102(1)-(2)(2000)$ [see U.C.C. $\$ 1-103$ (a) (revised 2005)] provides:

Purposes; Rules of Construction; Variation by Agreement.

(1) This Act shall be liberally construed and applied to promote its underlying purposes and policies.

(2) Underlying purposes and policies of this Act are

(a) to simplify, clarify and modernize the law governing commercial transactions;

(b) to permit the continued expansion of commercial practices through custom, usage and agreement of the parties;

(c) to make uniform the law among the various jurisdictions.

Id. 
effective. ${ }^{38}$

So when liberally construed, "in writing" means "oral"?

Not always. Official Comment 1 to section 1-102 states:

The text of each section should be read in the light of the purpose and policy of the rule or principle in question, as also of the Act as a whole, and the application of the language should be construed narrowly or broadly, as the case may be, in conformity with the purposes and policies involved. ${ }^{39}$

So you need to give the rule a "purposive" interpretation. ${ }^{40}$

I think I'm getting it. So, for example, Article 2 does not provide for consequential damages for a seller. ${ }^{41}$ But under the liberal construction, we could provide for them in an appropriate case where we determined that they served a remedial purpose?

Not exactly. There may be a distinction between interpreting a provision that is there and supplying one that is not. Your example does not interpret language, but supplies it.

But while Part 7 has all those formulas for computing remedies, aren't they trumped by the general principle stated in section 1-106, which provides that "remedies provided by this Act shall be liberally administered"? 42

Great observation, but the general principle in that section is qualified by more specific language providing that "neither consequential or special nor penal damages may be had except as specifically provided in this Act or by other rule of law." 43 And you are trying to supply consequential damages that are not specifically provided by the Code.

But couldn't it be argued that "as specifically provided by this Act" means subject to the purposive interpretation?

38 AMF, Inc. v. McDonald's Corp., 536 F.2d 1167, 1170-71 (7th Cir. 1976).

39 U.C.C. $\$ 1-102 \mathrm{cmt} .1$ (2000).

40 Julian B. McDonnell, Purposive Interpretation of the Uniform Commercial Code: Some Implications for Jurisprudence, 126 U. PA. L. REV. 795, 797 (1978).

41 See U.C.C. $\$ \$ 2-706,2-708$ (2000).

42 U.C.C. $\$ 1-106(1)(2000)$ [see U.C.C. $\$ 1-305(a)$ (revised 2005)] provides:

Remedies to Be Liberally Administered.

(1) The remedies provided by this Act shall be liberally administered to the end that the aggrieved party may be put in as good a position as if the other party had fully performed but neither consequential or special nor penal damages may be had except as specifically provided in this Act or by other rule of law.

Id.

${ }^{43} I d$ 
Interesting. I think a purposive interpretation of a rule might be "provided by this Act," but I don't think anything provided through interpretation is "specifically provided by this Act."

So Article 2 does not provide for consequential damages for a seller, either through interpretation or through a liberal administration of the remedies. So at least there is one rule that we know can't be changed.

Except that Amended Article 2 does provide for consequential damages for a seller. ${ }^{44}$ One of the purposes of the Code set forth in section 1-103 is "to simplify, clarify and modernize the law governing commercial transactions." 45 So it could be argued that this amendment is some indication of a modernizing trend of the law.

Umm, what is Amended Article 2?

We talked about the need to keep the Code up to date. In that spirit, a Revised Article 2 was drafted, but it proved too controversial and was ultimately not supported by NCCUSL. ${ }^{46}$ The drafters went back to the drawing board and came up with an Amended Article 2 in 2003. Note that calling it "amended" suggests that the changes are not as far-reaching as those of the "revised" version, which is true. But I'm afraid you don't have to worry about that for the near future, as the amended version has gained no traction. ${ }^{47}$

Speaking of bringing the Code up to date, I've always been confused by section 2-708 which says "the measure of damages for ... repudiation by the buyer is the difference between the market price at the time and place for tender and the unpaid contract price." 48 Wouldn't the better rule be to measure the market price at a reasonable time after the repudiation?

Yes. Everyone agrees that would be a salutary change. ${ }^{49}$ Indeed, that is

44 Amended $\S 2-708$ provides: "the measure of damages for nonacceptance by the buyer is the difference between the contract price and the market price at the time and place for tender together with any incidental or consequential damages provided in Section 2-710, but less expenses saved in consequence of the buyer's breach." U.C.C. $\S 2-708(1)(a)$ (amended 2003) (emphasis added).

45 U.C.C. $\S 1-102(2)$ (a) (2000) [see U.C.C. § 1-103(a)(1) (revised 2005)].

46 See Symposium, Perspectives on the Uniform Laws Revision Process, supra note 1. The text of Revised Article 2 may be found at http://www.law.upenn.edu /bll/ulc/ulc.htm; (select U.C.C. Article 2. Sales, then select Annual Meeting Draft 1999).

47 As of this writing, Amended Article 2 has not been enacted in any jurisdiction. See Uniform Law Commissioners: The National Conference of Commissioners on Uniform State

Laws http://www.nccusl.org/Update/uniformact_factsheets/uniformacts-fs-ucc22A03.asp (last visited Oct. 30, 2006).

48 U.C.C. $\$ 2-708(1)(2000)$.

49 See, e.g., JAMES J. WHITE \& ROBERT S. SUMMERS, UNIFORM COMMERCIAL CODE 270-71 (5th ed. 2000). 
one of the rules that was changed in Amended Article 2.50

So if it would be a better, more modern, rule, could a judge make that determination now as a "purposive" interpretation?

We said earlier that changing a provision is probably not the same as interpreting it.

But we also observed earlier in section 1-106 that remedies can be liberally administered, and this one does not fall within the exception. And didn't we also say that we should read in principles of equity, and isn't one of the principles of equity that where the reason for the rule changes, then the rule changes? ${ }^{51}$

By God, I think you're getting it!

But if judges can alter the declarations of the legislature, then doesn't that turn everything in this nonuniform noncommercial noncode into mere guidelines ${ }^{52}$

Indeed, you are getting it!

I notice you didn't answer my question.

You may have noticed I call this a "Socratic dialogue." That means I don't have to answer questions.

But how is one supposed to know all this?

Well, because we are having this dialogue.

But if one weren't so fortunate as to have you for an instructor?

It is part of the great common law tradition, except in this case, it is statutory tradition, or more precisely, Code tradition.

But if we wanted to look it up? Not that we would want to, in an era in which Justice Scalia tells us to look for the meaning of statutes in the

${ }^{50}$ U.C.C. $\S 2-708(1)(b)$ (amended 2003) provides:

[T] he measure of damages for repudiation by the buyer is the difference between the contract price and the market price at the place for tender at the expiration of a commercially reasonable time after the seller learned of the repudiation, but no later than the time stated in paragraph (a), together with any incidental or consequential damages provided in Section 2-710, less expenses saved in consequence of the buyer's breach.

Id.

51 See, e.g., CAL. CIV. CODE $\S 3510$ (West 1997), which provides: "Reason for rule ceasing. When the reason of a rule ceases, so should the rule itself."

52 See Pirates of the Caribbean: The Curse of the Black Pearl (Walt Disney Pictures 2003), in which Captain Barbossa explains to Elizabeth Swann that the Pirate Code is not really a code. No doubt analogizing to U.C.C. jurisprudence, he tells her, "It is more like-Arr-what you might call 'guidelines." Note that Arr is not to be confused with Aargh. See The Original Talk Like a Pirate Day Site, http://www.talklikeapirate.com. 
statutes. ${ }^{53}$ But if we did want to?

There is an excellent chapter on Code jurisprudence in the White and Summers treatise on the U.C.C. ${ }^{54}$ Or you could peruse some of the wonderful articles cited in the footnotes to our conversation.

And then we will understand the function of the Code as both regulatory and facilitatory?

You have Karl Llewellyn's word for it. He said of the Code, "The men who have studied it carefully have found their study turning them into enthusiasts. Doubts vanish like haze on a summer morning." 55

53 See generally ANTONIN SCALIA, A MATTER OF INTERPRETATION (1997).

54 JAMES J. WHITE \& ROBERT S. SUMMERS, Introduction to UNIFORM COMMERCIAL CODE (5th ed. 2000).

55 Karl N. Llewellyn, Remarks of August 16, 1954, in 1 REPORT OF THE LAW REVISION COMMISSION FOR 1954 AND RECORD OF HEARINGS ON THE UNIFORM Commerclal Code at 27 (N.Y. 1954) (quoted in Richard Danzig, A Comment on the Jurisprudence of the Uniform Commercial Code, 27 STAN. L. REv. 621, 621 (1975)). 
